\title{
Woman with Power to Construct and Exercise Strategies as Portrayed in 7 Wonders
}

\author{
Alicia $^{1}$, Liliek Soelistyo ${ }^{2}$ \\ English Department, Faculty of Languages and Literature, Petra Christian University, Siwalankerto 121-131, \\ Surabaya 60236, INDONESIA. \\ Email: alicia.nagaseta@gmail.com
}

\begin{abstract}
As a modernized version of the folktale Jaka Tarub dan Tujuh Bidadari, 7 Wonders applies the view that women should perform the Javanese concept of three Ms: masak, macak, and manak to please men while also acting weak around them. However, in the story, Nawang Wulan's actions do not indicate that she is weak. Instead, she can prove that she is a powerful woman who can construct her strategies to reach her goals. Thus, this study aims to discuss that the Nawang Wulan's strategies are altering their looks, using her support, and acting as weak woman. Each of the strategy displays her power and freedom to use the Javanese concepts of three $M s$ to please Jaka Tarub. As a result, she can persuade the him to help her reach her goals, and thus proves that her strategies can be used to control the him.
\end{abstract}

Keywords: Folktale, Girl Power, Men, Strategy, Women

\section{INTRODUCTION}

Webtoon is a digital comic that is specifically created for and published on a computer platform (Cho, 2016). It is a subgenre to manhwa that relies on the arrangement of pictures and words to tell stories. However, differing from printed comics, webtoon's stories are published digitally via the internet. This innovation allows not only readers to enjoy comics from all around the world but also provides comic artists the opportunities to create and publish their own stories. Each of the stories can entertain the readers while portraying the different cultures of their original country. This means that, when the webtoons are created by an Indonesian comic artist, then the stories usually convey Indonesian cultures, in which one of them is folktales or old traditional stories "from a particular place that was originally passed on to people in a spoken form" ("Folktale", 2020.) before they are recorded in written form. Usually, folktales are set in ancient times where people live simply and traditionally without the presence of any technology. This quality is maintained by a famous Indonesian webtoon artist called Metalu when he retells the folktale Jaka Tarub dan Tujuh Bidadari in his creation of 7 Wonders. In his webtoon, Metalu still follows the folktale's storyline in portraying the interaction of the angel Nawang wulan and Jaka Tarub.

7 Wonders elaborates on Nawang Wulan's efforts to reach her goal in having a family with Jaka Tarub. Yet, she does not explicitly state her wish to him but tries to win his favor by practicing the expectations on the way women should behave around men. Specifically, she becomes a helpful supporter to Jaka Tarub by adjusting her looks based on their current situation and defending him when the villagers accuse him for committing adultery with her. Her efforts eventually influence Jaka Tarub to develop feelings for her and trigger his willingness to grant her wish as a way to show affection. Nawang Wulan also displays her weakness by crying and running away from Jaka Tarub whenever they face a problem. By doing so, she can gain his consent to give her what she wants, which is having a family with him. Through her interaction with Jaka Tarub, I can see that following the expectations on the way women should behave around men can be beneficial in enabling her to reach her goals.

Nawang Wulan's success to reach her goal with the help of Jaka Tarub influences me to see that although she is described as weak in the folktale, it does not mean that she is powerless. Instead, 
she proves that she has the power to use anything to reach her goal. Thus, I am intrigued to know more about the way her actions in following the expectations on women's behavior can benefit her to obtain what she wants. This topic is fascinating to discuss because it can provide a new perspective regarding women who are often depicted as weak individuals.

In this analysis, I want to find out what kinds of strategies Nawang Wulan develop and exercise. I also want to know what are the results in exercising these strategies. Therefore, I want to show that Nawang Wulan's strategies are altering her looks, using her support as means of negotiation, and acting as weak women. As a result, she can change Jaka Tarub's perception on her as a woman and reach her goals with his help.

Traditional folktales, like Jaka Tarub dan Tujuh Bidadari, are usually created to both entertain and teach morality to its audience. By describing the female characters as weak and submissive partners to the male characters, folktales aim to teach women the appropriate attitude to behave around men. Yet, I find that although in 7 Wonders the female characters are described as weak and submissive people whose only duty is to take care of the male characters, it does not mean that they are completely powerless. Rather, they are powerful and clever individuals who can use anything to reach their goals.

I use two theories to find out more about Nawang Wulan's strategies. The first theory is the Javanese concept on ideal women. Since 7 Wonders is a modernized version of the folktale Jaka Tarub dan Tujuh Bidadari, it conveys the Javanese view that women must perform three $M s$ to become ideal women. Those three Ms are masak, macak, and manak. Masak refers to the women's task to become skillful in handling household duties and information for the good of the family (Narendra, 2015). Macak requires that women should use their physical appearance to attract the men's attention and to maintain the family's honor by never insulting their family or seduce other men who are not their partners (Narendra, 2015). Lastly, manak demands women to bear and raise children for the family. When Javanese women are able to perform all of these criteria, they will be considered as ideal women. The Javanese concept on three $M s$ is beneficial in this analysis by enabling me to see the way these norms are used by Nawang Wulan to construct her strategies to win Jaka Tarub's consent to help her reach her goals.

Aside from the Javanese concept on ideal women, I use girl power as my theory. Although girl power emerges as a popular slogan that was used from 1990s to 2000s to promote women empowerment, it strictly liberates women from their fear of becoming men's object of pleasure. Particularly, during the second wave feminism, women were expected to reject beauty and femininity to resist patriarchy. However, girl power suggests that embracing beauty do not make women powerless but rather provides them the truth and knowledge to gain equality. As elaborated by Bae, beautifying themselves is a form of self-improvement that provides "with the power that comes from achieving social distinction and attracting male attention" (Bae, 2011, p. 30). Therefore, when women choose to enhance their beauty and explore their sexuality, they can display their power and freedom to decide what is best for them. Girl power is beneficial in this analysis because it helps me to see the way Nawang Wulan chooses to perform all of the Javanese concepts of ideal women and use it as her strategy to prove that she is a powerful woman.

\section{METHOD}

In conducting this analysis, I focus on the story of 7 Wonders, using it as my primary data. Although 7 Wonders consists of three seasons, I limit my analysis into discussing the first season of the story because it portrays Nawang Wulan's interaction with Jaka Tarub. This means that I do not analyze the second season because the story revolves more around the male characters' effort to overpower each other nor the third season since the story is not finished yet. Since I want to prove that Nawang Wulan is a powerful woman who can develop various strategies to reach her goal, I need to reread the story and examine the way Nawang Wulan presents herself before Jaka Tarub. By doing so, 
I can see the way she constructs each of her strategies. For my secondary data, I use the Javanese concept of three $M s$ and girl power to get a better comprehension on Nawang Wulan's actions in using masak, macak, and manak as her strategy to gain Jaka Tarub's willingness to help her reach her goal.

In the analysis, I choose the scenes from the webtoon's episodes that depict Nawang Wulan's actions when she supports Jaka Tarub and displays her femininity. By doing so, I can show the way she constructs and exercises her strategy as well as her intentions. Afterward, I include the scenes where Jaka Tarub strives to fulfill Nawang Wulan's wish to show the results in exercising her strategies. I perform a close reading in the analysis by paying attention to the webtoon's pictures and dialogues to prove that Nawang Wulan is a powerful woman who consciously choose to perform femininity as her strategy to reach her goals.

\section{NAWANG WULAN'S POWER TO CONSTRUCT AND EXERCISE HER STRATEGIES}

As a modernized version of Jaka Tarub dan Tujuh Bidadari, 7 Wonders offers the story of Nawang Wulan and Jaka Tarub. Their interactions depict the way Nawang Wulan can develop and exercise her strategies to reach her goals to marry Jaka Tarub. By exploring the way these two characters interact with each other, I can prove that each of Nawang Wulan's efforts in practicing the three $M s$ enable her to have the power to get what she wants.

\subsection{NAWANG WULAN'S STRATEGIES}

Nawang Wulan's strategies are based on the Javanese standards of ideal women, which are the three $M s$. Performing these norms seem to justify that as a Javanese woman, Nawang Wulan revolves her lives around Jaka Tarub's needs and desires. Yet, her actions do not make her powerless but bestow her the power to win Jaka Tarub's favor and willingness to help her get what she wants. I discuss her strategies in the following sections below.

\subsubsection{Altering Her Looks}

Nawang Wulan exercises her first strategy by altering her looks. Although in the beginning she changes her appearance to protect herself from her pursuer, she can unintentionally attract Jaka Tarub's admiration toward her.

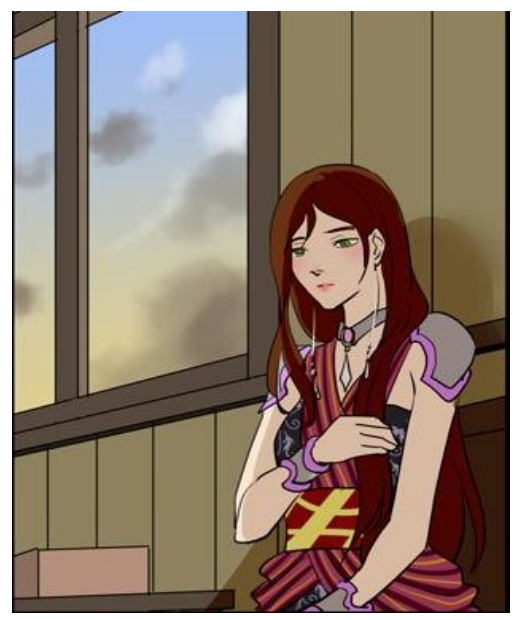

Picture 1: Nawang Wulan's first appearance.

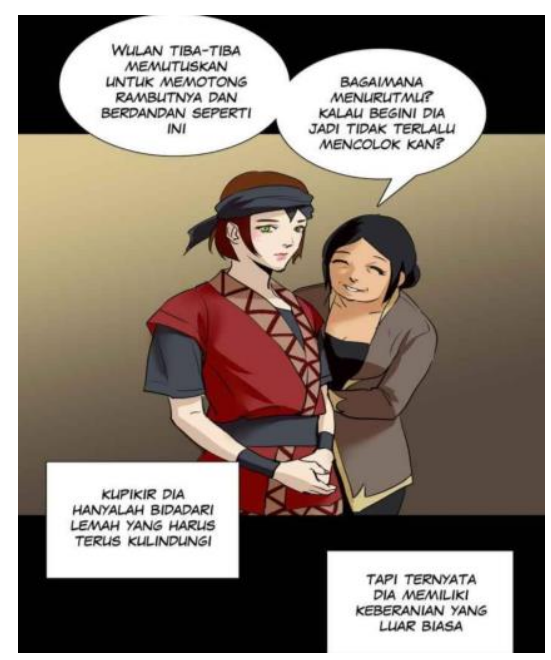

Picture 2: Nawang Wulan alters her looks.

After Nawang Wulan changes her looks, Jaka Tarub enters the room: The people that attacked you in the woods were a group of bandits who were quite famous for causing trouble 
Nagaseta, Soelistyo: Woman with Power to Construct and Exercise Strategies as Portrayed in 7 Wonders

around here. There is a possibility that they will search for you again, so you better hide at home. Don't let anyone look at you, especially when I'm not around.

Jaka Tarub gapes at Nawang Wulan's new looks in surprise.

Jaka Tarub's thoughts: I thought she is only a weak angel that should be protected. Yet, she has great courage.

From the pictures and dialogue above, Nawang Wulan's effort to alter her looks allows her to perform macak. Although generally macak demands that women should beautify themselves using beauty products, this norm also expects women to conform their looks to adapt with various events (Narendra, 2015). Her effort derives from her knowledge regarding the way her appearance is not suitable with her current situation. Specifically, she knows that maintaining her beauty can only attract her pursuers toward her. Since her goal is to hide from the pursuers, she diminishes her beauty by cutting her hair short and dresses like a man. The way Nawang Wulan alters her appearance shows that she is a powerful woman who possess the freedom to dress however she likes. Eventually, her efforts resulted in not only concealing herself from the pursuer but also unintentionally gaining Jaka Tarub's admiration as conveyed in the dialogue above. His reaction indicates that he never expects Nawang Wulan to do so. In other words, as a Javanese man, Jaka Tarub thinks that Nawang Wulan is a weak woman who need his protection, especially when she is hunted down by her pursuers, which is proven in his statement in telling her to stay home. Nonetheless, her efforts in altering her appearance rebuts Jaka Tarub's assumption that she needs to be fully protected by him. By doing so, Nawang Wulan proves that she is a powerful woman who has the freedom to use her looks to protect herself rather than relying on Jaka Tarub's protection.

\subsubsection{Using Support as Means of Negotiation}

Nawang Wulan's second strategy comes from her duty in fulfilling her duty as a mother. Following the folktale's storyline, 7 Wonders makes Nawang Wulan marries Jaka Tarub and bears their daughter, Nawangsih. The birth of her daughter causes Nawang Wulan to assume the role of a mother whose main responsibility is to take care of Nawangsih. Yet, fulfilling this duty does not make her powerless. Instead, it offers her the opportunity to negotiate with Jaka Tarub.

Jaka Tarub: If you really want to go home to khayangan, I'm willing to return to your sash. But you have to fulfill your responsibility as Nawangsih's mother. You know that Nawangsih really needs you now. I can't let her nurse from other women.

Nawang Wulan: Okay. I agree with your condition. Even though I return to khayangan and stay there, I will come back here on certain times and fulfill my duty as Nawangsih's mother. In the meantime, please build me a hut where I can nurse her. Can you accept my proposition?

Jaka Tarub: Yes, thank you for your understanding. (He takes out the sash from the box and gives it to Nawang Wulan).

In this dialogue, Nawang Wulan agrees to Jaka Tarub's condition to take care of their daughter. This action is in accordance with manak that expects Javanese women to take care of their children (Nafisah, 2016). Nawang Wulan's consent to nurse her daughter becomes her strategy to gain what she wants, which is obtaining her sash so that she can return to khayangan. This strategy comes from her knowledge regarding the way this action can affect Jaka Tarub. Specifically, agreeing to take care of their daughter allows Nawang Wulan to support him by showing that she still pays attention on his concerns, which then enables her to please him. It is important for Nawang Wulan to know this information because it allows her to use her support as her strategy in negotiating with Jaka Tarub (Balan, 2010). This is proven in the way she can express her terms with him by setting the time to 
nurture their daughter as well as asking for a hut. After they have agreed to these conditions, Nawang Wulan is able to get what she wants, which are having her sash back and return to khayangan. Her success in negotiating with Jaka Tarub regarding the way she is going to nurse their daughter proves that understanding his needs becomes an important element that enables her to use manak as her strategy (Balan, 2010). Nawang Wulan's actions also justify that although she agrees to assume her role as a mother, it does not mean she is powerless. Instead, it allows her to use her responsibility as her strategy to obtain Jaka Tarub's consent to give her what she wants.

\subsubsection{Acting as Weak Woman}

Finally, Nawang Wulan exercises her strategy by acting as weak woman. To do this, Nawang Wulan cries and accuses Jaka Tarub for stealing her sash. These actions may emphasize that as a woman, Nawang Wulan is weak and at the same time acknowledge Jaka Tarub is stronger than her. Yet, by crying and blaming him, Nawang Wulan can make him realize his mistake and trigger his willingness to mend for it as portrayed in the pictures and dialogues below.

Jaka Tarub: Nawang Wulan, calm down. I can explain.

Nawang Wulan: Lots of terrible things have happened because of this. Because I am here, the bandits attacked the village. Many innocent people died. Even your mother. Don't you feel any remorse? You're so mean, Dear! How could you lie to me?

Jaka Tarub (approaches Nawang Wulan): Nawang Wulan, listen to me.

Nawang Wulan: No! I don't trust you anymore!

Jaka Tarub (hugs Nawang Wulan): I'm sorry. Please stay with me. We already have Nawangsih. Can't you be happy with our little family?

Nawang Wulan (cries): You never understand me.

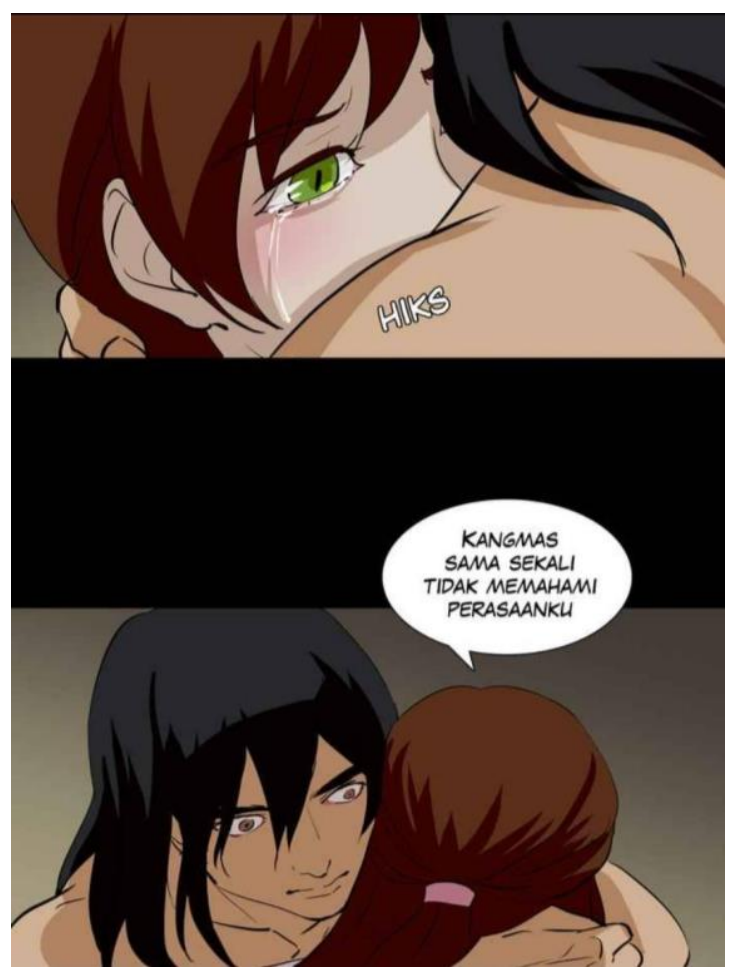

Picture 3: Nawang Wulan cries in front of Jaka Tarub 
In this part, Nawang Wulan acts as a weak woman by crying and blaming Jaka Tarub for everything that has happened. Crying may make her look unattractive since it disagrees with Bartky's view that women should always look appealing to men by acting timid and enhancing their beauty (Bartky, 1997). Specifically, crying makes her eyes puffy with tears streaming down her face and thus prevents her from displaying her beauty. Also blaming Jaka Tarub causes Nawang Wulan to look even more unattractive because she questions and intervenes with his intention, in which it contradicts with the way women are supposed to agree with everything that they men do (Becker, 1999). However, these actions can be used as a strategy because it makes her to look weak before Jaka Tarub. When she displays her weakness, she justifies that Jaka Tarub is a powerful man who can do anything to hurt her. Nawang Wulan's efforts in acting weak involve knowledge on the way crying and accusing Jaka Tarub can affect him. Strictly speaking, she knows that crying is the easiest way to gain men's consent because it makes women appear weak and vulnerable while at the same time accuses men from using their power to hurt the women. Blaming Jaka Tarub also involves knowledge on how his deed in stealing Nawang Wulan's sash has affected their lives. This knowledge is important because it allows her to play the role of a victim. These actions then affect Jaka Tarub by making him feel guilty for everything that he has done. His guilt becomes Nawang Wulan's chance to gain his willingness to do anything to fix his mistake, which is proven in his effort to remind her regarding their happiness. Through this interaction, Nawang Wulan prove that although crying and blaming Jaka Tarub causes her to display her vulnerability, it does not mean that she is completely powerless. Instead, by acting weak, Nawang Wulan can have the power to gain his consent to realize their mistake and mend for it.

\subsection{THE RESULTS IN EXERCISING NAWANG WULAN'S STRATEGIES}

Nawang Wulan exercises her strategies based on the Javanese concept of three $M s$ and femininity. Her actions cause her to prove that she is a powerful woman who can use her duties to please and support Jaka Tarub as her strategies. Apparently, each of her strategy affects Jaka Tarub by changing his perception on her as a woman as well as gaining his consent to help her reach her goals. I discuss the results in exercising Nawang Wulan's strategies in the following sections below.

\subsubsection{Changing Jaka Tarub's Perception Regarding Women}

In this part, Nawang Wulan is able to change Jaka Tarub's perception on her as a woman. As a Javanese man, Jaka Tarub agrees with the Javanese view that women are subordinate people whose main responsibility is to please men by exercising the three Ms. Yet, Nawang Wulan's strategies provide him with a different insight regarding her as a woman. These changes are elaborated in the dialogues below.

Nawang Wulan: I apologize for not coming here as soon as I used to, Dear. I'm very busy learning lots of things, so that I can get promoted.

Jaka Tarub: Why do you want that promotion?

Nawang Wulan: I hope that one day I can be a goddess, so that I can protect Nawangsih.

Jaka Tarub peaks inside the hut where Nawang Wulan is nursing Nawangsih.

Nawang Wulan: What you want, Dear? We agreed that I come here only to take care of Nawangsih.

Jaka Tarub's mind: Haah... She hasn't forgiven me. 


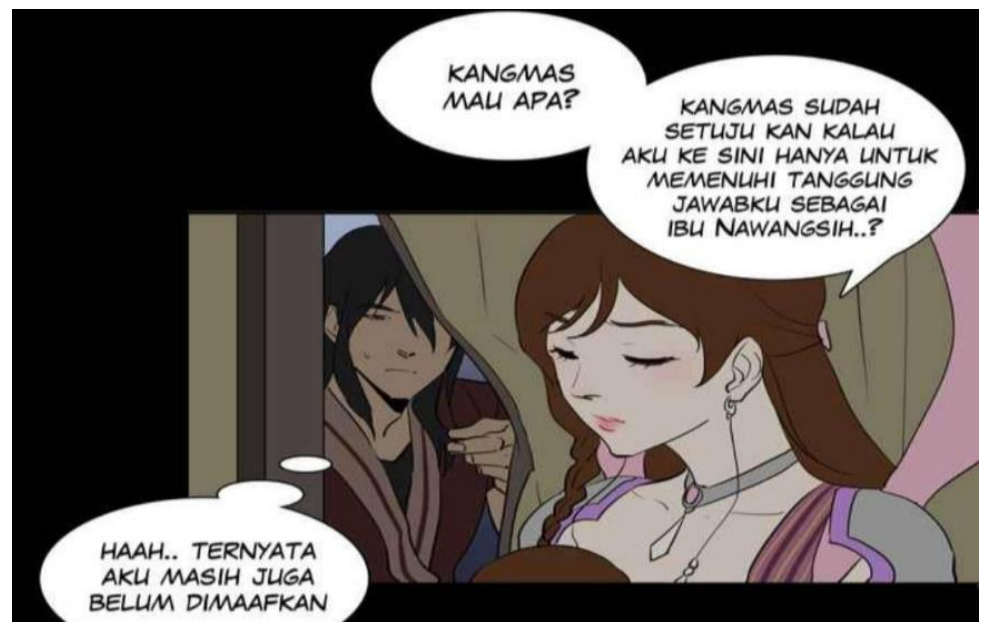

Picture 4: Nawang Wulan scolds Jaka Tarub for peaking inside the hut.

In this part, I discuss the three changes in Jaka Tarub's perspective. Firstly, Jaka Tarub sees Nawang Wulan as a powerful woman. Originally, he regards Nawang Wulan as kanca wingking, that implies woman is never seen as a man's equal because they share different duties. In other words, men are expected to work outside the house to ensure their safety whereas women are obliged to stay at home and please men with three Ms (Nafisah, 2013). However, after Nawang Wulan exercises her strategy, he no longer sees her as a weak woman but as a powerful person who can use her abilities to reach her goals. With this new perception, Jaka Tarub tries to accept Nawang Wulan's goal to get a promotion in khayangan, and thus proves that he sees her as his equal.

Next, Jaka Tarub regards Nawang Wulan's support as a necessity rather than a duty. As soon as Jaka Tarub marries Nawang Wulan, he never questions her actions because he believes that it is her duty as a woman to please men by practicing the three $M s$. However, after performing her strategies, Jaka Tarub realizes that he needs Nawang Wulan's support. Specifically, he believes that he cannot do anything without her assistance. Thus, when Nawang Wulan leaves him for khayangan, he is eager to gain her support back as conveyed in his wish to have her back as his wife. Jaka Tarub's response proves that although performing the three $M s$ enable Nawang Wulan to please him, it can become her strategies to change his mind. This success then indicates that Nawang Wulan is a powerful woman who can use anything to reach her goals.

Finally, Jaka Tarub acknowledges that Nawang Wulan has the right to be respected. As a Javanese man, Jaka Tarub used to think that women are wanita, that stands for wani ditata. This term proposes that women can be treated however men like without any objection (Nafisah, 2013). However, after Nawang Wulan acts weak by crying and blaming him, Jaka Tarub realizes that she has the right to be respected. This new perception then causes him to be careful with his actions, as portrayed in the picture where he does not dare to approach Nawang Wulan when she is nursing their daughter. Jaka Tarub's restrained actions prove that Nawang Wulan succeeds in showing that woman are not inferior people who can be treated however man likes. Instead, she emphasizes that woman has feelings and deserve the right to be treated with respect.

Through these three changes in Jaka Tarub, I see that Nawang Wulan's efforts in altering her looks, supporting him, and acting weak can be used as strategies. Performing these actions do not make her powerless but allows her to prove that she is a powerful woman who can use anything to reach her goals.

\subsubsection{Reaching Her Goal with the Help of Jaka Tarub}

Jaka Tarub's new perspective allows him to acknowledge Nawang Wulan's wish and grants it. Since Nawang Wulan desires to marry him and have a family with him, he immediately complies 
Nagaseta, Soelistyo: Woman with Power to Construct and Exercise Strategies as Portrayed in 7 Wonders

to her wish by proposing to her. Since marriage proposals are often defined as a question that is asked by the men to marry their partners ("Propose Marriage", 2020), then Nawang Wulan has the freedom to either accept or decline it. Apparently, she decides to accept Jaka Tarub's proposal and thus enables her to get all that she wishes for, as illustrated in the dialogues below.

Jaka Tarub (kneels in front of Nawang Wulan and offers her his hand): I've lost everything, and my hands are drenched with the people's blood that I've killed today. Do you still want me?

Nawang Wulan (sits on the ground while cradling the corpse of Jaka Tarub's mother who was recently killed. She wipes her tears.): Of course. (Takes Jaka Tarub's hand).

Flash forward to Jaka Tarub and Nawang Wulan holding their newborn daughter, Nawangsih.

Jaka Tarub: Thank God, you're both alright.

One night when Jaka Tarub is asleep.

Nawang Wulan reads a note from Jaka Tarub: 'I pick these flowers for you to express my apology for coming home late.' (Nawang Wulan eats the flowers.) How sweet. He reminds me of how fortunate I am for being with him.

Jaka Tarub's proposal shows that he acknowledges Nawang Wulan's wish and tries to grant it. This action is affected in the way he sees Nawang Wulan as his equal whose wishes matter, as proven in the way he proposes to her instead of forcing her to marry him. As soon as Nawang Wulan accepts the proposal, she is able to have one of her wishes, which is to marry Jaka Tarub. This marriage then allows her to obtain her wish in having a family with him in which she makes happen by bearing their daughter. All of Nawang Wulan's wishes cause her to take the role of a wife and a mother. Yet, assuming these roles do not make her powerless but displays her freedom to choose anything that she wants and be content with it. Her actions then prove that as a woman, she has the power to make decisions for herself and construct any strategies to reach her goals.

\section{CONCLUSION}

Through this analysis, I find that although women in folktales are often portrayed as weak people who revolve their lives around men, it does not mean that they are completely powerless. Instead, women are powerful people who can use anything, including men, to reach their goals. In the case of Nawang Wulan, she uses the Javanese concept of three $M s$ and her femininity as her strategies. Exercising these actions enable her to both please Jaka Tarub and trigger his willingness to help her reach her goals. As a result, Nawang Wulan is able to get everything that she wishes for with the help of Jaka Tarub. Through their interaction, I find that women possess the power to control men into granting anything that they want. This power also enables women to choose anything that they want. Particularly, when they want to become a wife and a mother, it does not mean that they are weak. Instead, it displays their freedom to choose anything that is best for them and be content with it.

\section{REFERENCES}

Bae, M. S. (2011). Interrogating Girl Power: Girlhood, popular media, and postfeminism. Visual Arts Research,. 37(2), 28-40. doi:10.5406/visuartsrese.37.2.0028

Balan, S. (2010). M. Foucault's view on power relations. Retrieved from https://www.academia.edu/37709536/M._FOUCAULTS_VIEW_ON_POWER_RELATION S

Bartky, S. L. (1997). Foucault, Femininity, and the Modernization of Patriarchal Power. In Writing on the Body: Female Embodiment and Feminist Theory (p. 129-154). New York: Columbia 
University Press. Retrieved from

https://mycourses.aalto.fi/pluginfile.php/198021/mod_page/content/8/Bartky129_HIAR11034 .pdf

Becker, M. (1999). Patriarchy and inequality: Towards a substantive feminism. University of Chicago Legal Forum, 1999(1), 21-88. Retrieved from http://chicagounbound.uchicago.edu/uclf/vol1999/iss1/3

Cho, H. (2016, July 18). The webtoon: A new form of graphic narrative. The Comics Journal. Retrieved from http://www.tcj.com/the-webtoon-a-new-form-for-graphic-narrative/

Definition of Folktale. (2020). In Oxford Learner's Dictionaries. Retrieved from https://www.oxfordlearnersdictionaries.com/definition/english/folk-tale

Definition of Marriage Proposal. (2020). In Merriam-Webster Dictionary. Retrieved from https://www.merriam-webster.com/dictionary/propose\%20marriage

Metalu. (2016). 7 Wonders. [Webtoon.] Retrieved from https://www.webtoons.com/id/fantasy/7wonders/list?title_no=699

Nafisah, S. (2016). Konsep gender terhadap peran perempuan dalam budaya Jawa. Retrieved from https://www.academia.edu/33408596/KONSEP_GENDER_TERHADAP_PERAN_PEREMP UAN_DALAM_BUDAYA_JAWA?auto=download

Narendra, S. (2015). Masak, macak, lan manak. Kompasiana. Retrieved from https://www.kompasiana.com/rendra13/551fabbb81331151019dfc1f/masak-macak-lanmanak 